\title{
Updates to the standardized reporting guidelines endorsed by the Journal
}

\author{
Donald Miller, MD • François Donati, MD, PhD • \\ Penelope Brasher, PhD · Scott Beattie, MD • \\ David Mazer, MD
}

Published online: 16 December 2009

(C) Canadian Anesthesiologists' Society 2009

Consistent with the stance of leading journals in the specialty, the editorial board of the Canadian Journal of Anesthesia staunchly advocates clear scientific writing and transparent reporting of all research. We do so by endorsing key standardized reporting guidelines, advocating the uniform reporting requirements of the International Committee of Medical Journal Editors (ICMJE), and ensuring that the decision letters we send to authors respectfully provide sound and expert guidance to foster improved accuracy and clarity in their revised articles and subsequent reports. Our "Instructions for Authors" are regularly updated online (www.springer.com/12630 and www.edmgr.com/cja) to reflect evolving editorial policies, present essential information regarding the required content of submitted articles, and provide numerous hyperlinks that serve as easy navigation tools to related resources for authors. In recent editorials, we have addressed several of the most commonly identified reporting problems in manuscripts submitted to

D. Miller, MD

University of Ottawa, Ottawa, ON, Canada

F. Donati, MD, PhD

University of Montreal, Montreal, QC, Canada

P. Brasher, PhD

University of British Columbia, Vancouver, BC, Canada

S. Beattie, MD - D. Mazer, MD

University of Toronto, Toronto, ON, Canada

D. Miller, MD $(\varangle)$

The Editorial Office, Canadian Journal of Anesthesia,

The Ottawa Hospital, General Campus CCW 1409,

501 Smyth Road, Ottawa, ON K1H 8L9, Canada

e-mail: dmiller@ottawahospital.on.ca the Journal, including problems relating to sample size estimation ${ }^{1}$ and statistical issues associated with multiplicity. $^{2}$ Furthermore, we are making a considerable effort to enhance the rigour of our editorial peer review process, including the statistical reviews. While there is recent evidence of a gradual improvement in the overall quality of reported trials in this and other anesthesia journals, ${ }^{3}$ there is more work to be done. Although the overall rationale for reporting guidelines was recently addressed, ${ }^{4}$ over 90 reporting guidelines currently exist. Some guidelines are regularly updated and evidence-based, while others are not. The purpose of this editorial is to provide an update regarding the three reporting guidelines that the Journal currently endorses. These reporting guidelines should serve as equally important resources for authors submitting original research and for the reviewers and editors who evaluate the submitted articles.

\section{Randomized trials: the CONSORT statement}

Several years ago, the Journal adopted the CONsolidated Standards $O$ f Reporting Trials (CONSORT) Statement (http://www.consort-statement.org), which is an evidencebased minimum set of recommendations for reporting randomized controlled trials (RCTs). ${ }^{5}$ The most recent version comprises an updated 22 -item checklist and a diagram that illustrates the flow of patients throughout a trial. It is our policy to publish this type of flow diagram for larger trials, whereas the essential details of smaller clinical trials can usually be presented in several sentences in the "Method" section of the related article. In our "Instructions for Authors", we advise authors to refer to the CONSORT statement during manuscript preparation of RCTs and to upload the completed checklist during 
submission. The checklist should identify the corresponding page number where each of the 22 items is reported.

In following the elements of the CONSORT statement during the editorial review process, we have identified several recurrent problems. For example, we continue to observe incomplete or inconsistent reporting of the statistical methods used to compare primary outcome(s) and the methods used for analysis of secondary outcomes and subgroup analysis (CONSORT Item \#12). To avoid these and related statistical problems, we encourage authors to consult with an experienced biostatistician at the time of trial design and during the subsequent data analysis. Another recurrent problem is the tendency for authors to blur the very important distinction between sequence generation in the randomization process (CONSORT Item \#8) and the method of allocation concealment (also part of the randomization process-CONSORT Item \#9). Sequence generation is the method used to generate the random sequence to ensure comparability of the study groups. Allocation concealment is the method used to implement the random sequence (eg. numbered containers or central telephone) to ensure that this sequence was concealed from those enrolling participants into the study. Randomization is a critically important element of trial design to ensure comparability of the intervention and control groups on any known or unknown potential confounder. Concealment is equally important if the problem of treatment allocation (selection) bias is to be avoided. If the method of allocation concealment in an RCT is not reported, it is impossible to know if a concealment process was actually followed and thus the potential for bias cannot be ruled out. The process should be reported transparently. For further details on CONSORT, please refer to the supporting explanation and elaboration document. ${ }^{6}$

\section{Observational studies: the STROBE statement}

The CONSORT statement applies to reports of RCTs only. Recognizing that observational studies may also provide valid scientific information, reporting guidelines have also been developed for these types of studies. The reporting guidelines for STrengthening the Reporting of OBservational studies in Epidemiology (STROBE) Statement (http://www.strobe-statement.org) were published in 2007 and provide recommendations for the three main analytical designs used in observational research, i.e., cohort, case control, and cross-sectional studies. ${ }^{7}$ The Journal now adopts the STROBE guidelines. Consistent with CONSORT, STROBE 2007 includes a unique 22-item checklist of elements to include in reports of observational studies. As observational studies are prone to issues of selection bias and variably recorded data and outcomes, these items are carefully scrutinized during our peer review process to ensure that methods to address these and other issues have been attended to and explained. In our "Instructions for Authors", we advise authors to refer to the STROBE statement during manuscript preparation of observational studies and to upload the completed checklist during submission. The checklist should identify the corresponding page number where each of the 22 items is reported. In following the elements of the STROBE statement during the editorial review process we have identified Item 7, "Variables" as especially problematic. When reporting observational studies authors invariably rely on multivariable models and yet seldom do they provide any information regarding why variables were considered for inclusion in the model. For further details regarding STROBE, please refer to its supporting explanation and elaboration document. ${ }^{8}$

\section{New for systematic reviews and meta-analyses: the PRISMA statement}

The Cochrane definition of a systematic review is one with a clearly formulated question that uses systematic and explicit methods to identify, select, and critically appraise relevant research, and analyze data from the studies included in the review. ${ }^{9}$ Meta-analyses may be used to analyze and summarize the results of included studies. The Journal has most recently adopted the newly published Preferred Reporting Items for Systematic Reviews and Meta-Analyses (PRISMA) Statement 2009 (www.prismastatement.org) as our preferred reporting guideline for systematic reviews and meta-analyses. PRISMA is an evidence-based minimum set of reporting standards that includes a 27 -item checklist and a four-phase diagram that depicts the flow of information through the different phases of a systematic review. ${ }^{10}$ The universal resource locator (URL) of the PRISMA statement is hyperlinked in our "Instructions for Authors" (as are CONSORT and STROBE) and replaces the pre-existing QUOROM statement.

The PRISMA statement addresses several conceptual and practical advances in the science of systematic reviews. PRISMA recognizes the concept that completing a systemic review is an iterative process, such that systematic reviewers may need to modify the original protocol during the conduct of the study, and such changes should be reported and explained (PRISMA Items \#5, 11, 16, and 23). Other important concepts in the evolution of PRISMA, including study-level vs outcome-level assessment of risk of bias and the importance of reporting bias are explained in the PRISMA statement and its supporting document. ${ }^{11}$ While the PRISMA statement focuses on analysis of RCTs, 
it should not, however, be used as a quality assessment instrument to evaluate the quality of a systematic review. In our recently updated "Instructions for Authors", we advise authors to refer to the PRISMA statement during manuscript preparation of systematic reviews and to upload the completed checklist during submission. The checklist should identify the corresponding page number where each of the 27 items is reported.

Finally, a new and complementary resource for authors submitting to the Journal can be found on the new EQUATOR (Enhancing the QUAlity and Transparency of health Research) network website (www.equator-network.org). The EQUATOR network was launched in 2008 as an international collaboration designed to enhance the reliability of medical literature by promoting accurate and transparent reporting of research. ${ }^{12}$ The major goals of the network are to develop and maintain a comprehensive internet-based resource centre of tools and materials relating to health research reporting and to assist in the development and dissemination of robust reporting guidelines. We encourage authors to visit the EQUATOR website. The network provides valuable resources for authors and editors and updates these resources regularly. In time, the objective is for the EQUATOR network to monitor the implementation of reporting guidelines and to study their impact on the quality of reporting across journals.

\section{Conclusions}

Authors will become aware of the increasing rigour of our editorial peer review process through which we make considerable effort to ensure the articles we publish in the Journal are of the highest possible quality. Many articles are rejected without peer review due to extensive reporting and methodological problems. Prior to final acceptance for publication, manuscripts may require at least two and sometimes three or four revisions to address the reporting issues and methodological concerns raised during the review. We recognize that there is no perfect study and no perfect manuscript; however, clear and transparent reporting leads to more favourable reviews, increases the likelihood of acceptance, and most importantly, helps our readers and other researchers to formulate their own judgments and conclusions based on the reported data. The reporting should be sufficiently detailed to permit a reader with access to the original data to generate similar findings from those reported. Adherence to sound, evidence-based standardized reporting guidelines is a fundamental step in this evolutionary process. Meanwhile, we keenly await further evidence regarding the impact of reporting guidelines on the medical literature.

\section{Mises à jour des directives normalisées de présentation approuvées par le Journal}

En accord avec la position des principales revues de notre spécialité, le bureau de rédaction du Journal canadien d'anesthésie est un fervent défenseur d'une formulation scientifique claire et transparente pour toute présentation de travaux de recherche. Pour ce faire, nous appuyons les principales directives normalisées de présentation en préconisant le respect des exigences uniformes de l'International Committee of Medical Journal Editors (ICMJE) et en nous assurant que les lettres de décision que nous envoyons aux auteurs proposent des conseils avisés et experts, lesquels permettront aux auteurs d'améliorer la précision et la clarté de leurs articles révisés et de leurs travaux ultérieurs. Nos «Directives aux auteurs» sont régulièrement mises à jour en ligne (www.springer. com/12630 et www.edmgr.com/cja) afin de refléter l'évolution des politiques rédactionnelles, de présenter des informations essentielles quant au contenu requis des articles soumis, et de fournir de nombreux hyperliens qui permettent aux auteurs de consulter facilement d'autres ressources pertinentes. Les éditoriaux récents ont abordé plusieurs des problèmes de présentation les plus fréquemment rencontrés dans les manuscrits soumis au Journal, y compris ceux liés à l'estimation de la taille d'échantillon ${ }^{1}$ et aux questions statistiques associées à la multiplicité. ${ }^{2}$ De plus, nous déployons des efforts considérables afin d'améliorer la rigueur de notre processus d'évaluation par les pairs, notamment pour les statistiques. Bien que nous ayons récemment observé une amélioration progressive de la qualité générale des comptes-rendus d'études dans notre revue et dans d'autres revues d'anesthésie, ${ }^{3}$ nous avons encore du pain sur la planche. Quoique la justification globale des directives de présentation ait été récemment abordée, ${ }^{4}$ il existe actuellement plus de 90 directives. Certaines de ces directives sont mises à jour régulièrement et sur la base de données probantes, alors que d'autres ne le sont pas. L'objectif de cet éditorial est d'offrir une mise à jour au sujet des trois directives de présentation que le Journal approuve actuellement. Ces directives devraient constituer des ressources tout aussi importantes pour les auteurs soumettant des travaux de recherche originaux que pour les lecteurs et les rédacteurs qui évaluent les articles soumis. 


\section{Études randomisées: L'énoncé CONSORT}

Il y a plusieurs années, le Journal adoptait l'énoncé CONSORT (CONsolidated Standards Of Reporting Trials - http://www.consort-statement.org), un ensemble de recommandations minimales basées sur des données probantes pour la préparation d'études randomisées contrôlées (ERC). ${ }^{5}$ La version la plus récente de cet énoncé comprend une liste de contrôle mise à jour de 22 éléments ainsi qu'un organigramme illustrant le cours des patients tout au long d'une étude. Notre politique est de publier ce type de diagramme pour les grandes études, alors que les détails essentiels d'études cliniques plus petites peuvent en général être résumés en quelques phrases dans la section « méthode» de l'article présenté. Dans nos «Directives aux auteurs », nous conseillons aux auteurs de se reporter à l'énoncé CONSORT pendant la préparation d'un manuscrit d'ERC et de téléverser la liste de contrôle complétée lors de la soumission de leur manuscrit. La liste de contrôle devrait mentionner le numéro de page sur lequel on peut trouver chacun des 22 éléments correspondants.

En se basant sur les éléments de l'énoncé CONSORT pendant le processus de révision éditoriale, nous avons identifié plusieurs problèmes récurrents. Par exemple, nous constatons encore une formulation incomplète ou incohérente des méthodes statistiques utilisées pour comparer le ou les critères d'évaluation principaux de même que les méthodes utilisées pour l'analyse des critères d'évaluation secondaires et l'analyse par sous-groupe (élément CONSORT \#12). Afin d'éviter ces problèmes statistiques et d'autres problèmes qui y sont associés, nous recommandons aux auteurs de consulter un biostatisticien expérimenté lors de la conception de l'étude et pendant l'analyse ultérieure des données. Un autre problème récurrent est la tendance de certains auteurs de brouiller la distinction essentielle entre la génération de séquences durant le processus de randomisation (élément CONSORT \#8) et la méthode de dissimulation de l'attribution (également partie du processus de randomisation - élément CONSORT \#9). La génération d'une séquence est la méthode utilisée pour générer la séquence aléatoire afin de s'assurer que les groupes à l'étude sont comparables. La dissimulation de l'attribution est la méthode utilisée pour mettre en œuvre la séquence aléatoire (par ex. des conteneurs numérotés ou un téléphone central) afin de s'assurer que cette séquence était dissimulée des personnes recrutant les participants à l'étude. La randomisation est un élément crucial de la méthodologie d'étude qui permet de garantir la comparabilité des groupes d'intervention et du groupe témoin par rapport à tout élément potentiellement confondant connu ou inconnu. La dissimulation est tout aussi importante si l'on veut éviter le problème de biais dans l'attribution (sélection) du traitement. Si la méthode de dissimulation de l'attribution d'une ERC n'est pas énoncée, il est impossible de savoir si un processus de dissimulation a effectivement été respecté; dès lors, on ne peut exclure un biais potentiel. Ce processus devrait être énoncé de façon transparente. Si vous souhaitez obtenir plus d'informations au sujet de l'énoncé CONSORT, veuillez vous référer au document explicatif et d'élaboration à l'appui. ${ }^{6}$

\section{Études observationnelles: L'énoncé STROBE}

L'énoncé CONSORT ne s'applique qu'aux comptes-rendus d'ERC. Étant donné que les études observationnelles peuvent également présenter des informations scientifiques valables, des directives de présentation ont également été élaborées pour ce type d'études. Les directives de l'énoncé STROBE (STrengthening the Reporting of $O B$ servational studies in Epidemiology - http://www.strobe-statement. org) ont été publiées en 2007 et fournissent des recommandations pour les trois principales méthodologies analytiques en recherche observationnelle, soit les études de cohorte, les études cas-témoins et les études transversales. ${ }^{7}$ Le Journal adopte désormais les directives STROBE. Tout comme c'est le cas dans l'énoncé CONSORT, l'énoncé STROBE 2007 comprend une liste de contrôle exclusive de 22 éléments à inclure dans les comptes-rendus d'études observationnelles. Étant donné que les études observationnelles ont tendance à contenir des problèmes de biais de sélection et que les données et les résultats sont recueillis de façon très variable, les éléments de cette liste de contrôle sont analysés avec soin pendant notre processus d'évaluation par les pairs et ce, afin d'assurer que les méthodes utilisées pour aborder ces questions ont été prises en compte et expliquées. Dans nos « Directives aux auteurs », nous conseillons aux auteurs de se reporter à l'énoncé STROBE pendant la préparation d'un manuscrit d'étude observationnelle et de téléverser la liste de contrôle complétée lors de la soumission de leur article. La liste de contrôle devrait mentionner le numéro de page sur lequel on peut trouver chacun des 22 éléments correspondants. En se basant sur les éléments de l'énoncé STROBE pendant le processus de révision éditoriale, nous avons découvert que l'élément 7, "Variables », était particulièrement problématique. Lors du compte-rendu d'études observationnelles, les auteurs se basent systématiquement sur des modèles multivariables mais ne présentent que rarement les informations concernant la raison pour laquelle on a pensé à inclure ces variables dans le modèle. Si vous souhaitez obtenir plus d'informations au sujet de l'énoncé STROBE, veuillez vous référer au document explicatif et d'élaboration à l'appui. ${ }^{8}$ 
Du nouveau pour les revues méthodiques et les méta-analyses: L'énoncé PRISMA

Selon le groupe Cochrane, une revue méthodique se définit par une question clairement formulée qui utilise des méthodes systématiques et explicites pour identifier, sélectionner et évaluer de façon critique les résultats pertinents de la recherche, en plus d'une analyse des données des études inclues dans la revue. ${ }^{9}$ Les méta-analyses peuvent être utilisées pour analyser et résumer les résultats des études inclues. Tout récemment, le Journal a adopté l'énoncé PRISMA 2009 (Preferred Reporting Items for Systematic Reviews and Meta-Analyses - www.prisma-statement.org) en tant que directive de prédilection pour les revues méthodiques et les méta-analyses. L'énoncé PRISMA est un ensemble minimum de normes de présentation basées sur des données probantes qui comprend une liste de contrôle de 27 éléments et un diagramme en quatre phases décrivant le trajet des informations entre les différentes phases d'une revue méthodique. ${ }^{10}$ L'adresse universelle (Universal Resource Locator ou URL) de l'énoncé PRISMA est disponible en hyperlien dans nos « Directives aux auteurs » (tout comme celles des énoncés CONSORT et STROBE) et remplace l'énoncé préexistant QUOROM.

L'énoncé PRISMA aborde plusieurs progrès conceptuels et pratiques de la science des revues méthodiques. L'énoncé PRISMA reconnaît l'idée qu'une revue méthodique est un processus itératif, de telle sorte que les chercheurs menant une revue méthodique pourraient devoir modifier le protocole initial pendant la réalisation de l'étude; de telles modifications doivent être rapportées et expliquées (éléments PRISMA \#5, 11, 16 et 23). D'autres concepts importants dans l'évolution de PRISMA, notamment l'évaluation du risque de biais au niveau de l'étude versus au niveau des résultats, ou encore l'importance de rendre compte d'un biais, sont expliqués dans l'énoncé PRISMA et dans son document à l'appui. ${ }^{11}$ Bien que l'énoncé PRISMA soit consacré à l'analyse des ERC, il ne devrait cependant pas être utilisé comme outil d'évaluation de la qualité d'une revue méthodique. Dans nos « Directives aux auteurs » récemment mises à jour, nous conseillons aux auteurs de se reporter à l'énoncé PRISMA pendant la préparation d'un manuscrit d'étude méthodique et de téléverser la liste de contrôle complétée lors de la soumission de leur article. La liste de contrôle devrait mentionner le numéro de page sur lequel on peut trouver chacun des 27 éléments correspondants.

Enfin, une nouvelle ressource complémentaire pour les auteurs soumettant leur manuscrit au Journal est disponible sur le nouveau site du réseau EQUATOR (Enhancing the QUAlity and Transparency of health
Research - www.equator-network.org). Le réseau EQUATOR a été lancé en 2008. Il s'agit du fruit d'une collaboration internationale conçue pour améliorer la fiabilité de la littérature médicale en promouvant une formulation précise et transparente des résultats de recherche. ${ }^{12}$ Les principaux objectifs du réseau sont de mettre sur pied et maintenir un centre de ressources complet basé sur Internet qui met à disposition des outils et du matériel liés à la présentation d'études de recherche en santé et d'aider à l'élaboration et à la diffusion de directives de présentation solides. Nous recommandons aux auteurs de consulter le site Internet EQUATOR. Le réseau offre aux auteurs et aux rédacteurs des ressources précieuses qui sont mises à jour régulièrement. L'objectif ultime du réseau EQUATOR est de surveiller la mise en œuvre de directives de présentation et d'étudier leur impact sur la qualité des articles dans les différentes revues.

\section{Conclusion}

Les auteurs vont se rendre compte de la rigueur croissante de notre processus d'évaluation par les pairs, durant lequel nous déployons beaucoup d'efforts pour garantir que les articles que nous publions dans le Journal sont de la qualité la plus élevée possible. Nombre d'articles sont rejetés sans révision par les pairs en raison des problèmes majeurs qu'ils comportent au niveau de la présentation et de la méthodologie. Avant d'être finalement acceptés pour publication, les manuscrits peuvent nécessiter au moins deux et parfois trois ou quatre révisions de façon à résoudre les problèmes de présentation et de méthodologie soulevés pendant la révision. Nous sommes conscients qu'il n'existe pas d'étude parfaite, ni de manuscrit parfait; cependant, une formulation claire et transparente génère des évaluations plus favorables, augmente la probabilité d'acceptation du manuscrit, et surtout, aide nos lecteurs et les autres chercheurs à formuler leurs propres jugements et conclusions sur la base des données rapportées. La présentation doit être suffisamment détaillée afin de permettre à un lecteur ayant accès aux données originelles de générer des résultats semblables à ceux qui sont rapportés. Le respect de bonnes directives normalisées de présentation basées sur des données probantes est une étape fondamentale de ce processus d'évolution. Entre-temps, nous attendons avec impatience d'avoir davantage de données concernant l'impact de ces directives sur la littérature médicale.

Conflicts of interest None declared. 


\section{References}

1. Brasher PM, Brant RF. Sample size calculations in randomized trials: common pitfalls. Can J Anesth 2007; 54: 103-6.

2. Brasher PM, Brant RF. Problems of Multiplicity. Can J Anesth 2008; 55: 259-64.

3. Greenfield ML, Mhyre JM, Mashour GA, et al. Improvement in the quality of randomized controlled trials among general anesthesiology journals 2000 to 2006: a 6-year follow-up. Anesth Analg 2009; 108: 1916-21.

4. Moher D. Guidelines for reporting health care research: advancing the clarity and transparency of scientific reporting. Can J Anesth 2009; 56: 96-101.

5. Moher D, Schulz KF, Altman DG. The CONSORT statement: revised recommendations for improving the quality of reports of parallel-group randomised trials. Lancet 2001; 357: 1191-4.

6. Altman DG, Schulz KF, Moher D, et al. The revised CONSORT statement for reporting randomized trials: explanation and elaboration. Ann Intern Med 2001; 134: 663-94.

7. von Elm E, Altman DG, Egger M, et al. The strengthening the Reporting of Observational Studies in Epidemiology (STROBE) statement: guidelines for reporting observational studies (Spanish). Rev Esp Salud Publica 2008; 82: 251-9.
8. Vandenbroucke JP, von Elm E, Altman DG, et al. Strengthening the Reporting of Observational Studies on Epidemiology (STROBE): explanation and elaboration. Ann Int Med 2007; 147: W163-94.

9. Green S, Higgins J (Editors). Glossary. Cochrane Handbook for Systematic Reviews of Interventions 4.2.5 (updated May 2005). The Cochrane Collaboration. Available from URL: http://www. cochrane.org/resources/glossary.htm. Accessed September 2009.

10. Moher D, Liberati A, Tetzlaff J, Altman DG, The Prisma Group. Preferred reporting items for systematic reviews and meta-analyses: the PRISMA statement (Chinese edition) (Chinese). Zhong Xi Yi Jie He Xue Bao 2009; 7: 889-96.

11. Liberati A, Altman DG, Tetzlaff $J$, et al. The PRISMA statement for reporting systemtic reviews and meta-analyses of studies that evaluate health care interventions: explanation and elaboration. J Clin Epidemiol 2009; 62: e1-34.

12. Moher D, Simera I, Schulz KF, Hoey J, Altman DG. Helping editors, peer reviewers and authors improve the clarity, completeness and transparency of reporting health research. BMC Med 2008; 6: 13. 